\section{THE STRUCTURE OF CRYSTALS.1}

$\mathrm{I} \mathrm{T}$ is impossible here to do more than call attention to these two memoirs; the subject with which they deal is too intricate to be intelligible without the aid of diagrams.

The author of the first appears to hold quite peculiar views on the nature of valency and chemical combination Each atom is surrounded by a "sphere of action," and this represents the volume of the element; whereas the volume of a compound molecule is less than the sum of the volumes of its components, for their spheres of action are supposed to interpenetrate to a certain extent when combination takes place. Their partial interpenetration gives rise to a complex surface of action for the molecule, which may be of a polar character, and approximates in form to a sphere when the molecule consists of a large number of atoms. Crystallisation is due to the attractive juxtaposition of such polar molecules. For the author's general views the reader is referred to his previous work, "Die Kraft und Materie in Raume."

The present memoir is an elaborate study of the development of a number of complex forms by the superposition of spheres layer by layer on one or other of a few simple " embryos"; for example, on a tetrahedron composed of four equal spheres in contact. The whole process is illustrated by twenty six excellen plates, which appear to be photographs of skilfully constructed stacks of balls. On all matters the author expresses himsel with remarkable confidence, and claims to have solved the problem of crystallisation.

We doubt, however, whether all the types of crystalline symmetry are covered by the author's hypotheses, and some of his groups appear to be incompatible with what is known of crystals.

Mr. Barlow's first communication on the subject of crystalline structure was made to this journal (vol. xxix. p. I86) in I883, and was also illustrated by the regular grouping of spheres of different sorts. That paper was characterised as "an interesting and ingenious memoir" by the late Prof. Sohncke, who expressed the hope that his own criticisms (p. 383) would induce the author " to establish his theory in a more solid and more general way." Since that date Mr. Barlow has published several investigations on the subject, and the present memoir, which appears in the scientific Proceedings of the Royal Dublin Society, is an extended study of the close-packing of spheres of different sizes. In the arrangement and re-arrangement of such stacks he ingeniously traces a number of interesting analogie which lead him far beyond the features of mere crystalline growth and structure into chemical combination and decom position, solution, diffusion, and the phenomena classed under stereo-chemistry.

Mr. Barlow himself regards the close packing of spheres as representing the position of equilibrium of mutually repellent particles, and this he believes to be the key to all the problems considered; but the reader must be referred to the original memoir for the details.

The study of crystalline structure as represented by the close packing of spheres or other figures is now being prosecuted by several investigators in very different ways, and with very different interpretations. The geometry of the subject is, of course, independent of all the speculations which gather round it, and deserves the very serious attention of chemists and physicists.

\section{UNIVERSITY AND EDUCATIONAL INTELLIGENCE.}

CAmbridge. - Mr. Oldham, the University Lecturer in Geography, announces a public lecture on the North-west Frontier of India. Sir George Robertson, K.C.S.I., of Chitral fame, will take the chair.

The late Mr. Frank Chance has bequeathed 400 volumes to the University Library.

The Museums Syndicate report that owing to the increase of the number of buildings under their charge, and the greater requirements for research and other students, the sum placed at their disposal for the annual maintenance of the scientific departments must be augmented by $300 l$.

1 “Das Problem der Krystallisation." By A. Turner. Pp. $98 ; 26$ plates. (Leipzig: 1897.)

"A Mechanical Cause of Homogeneity of Structure and Symmetry geometrically investigated; with special application to Crystals and to Chemical Combination." By. W. Barlow. Pp. ró4. (Dublin : 1897.)

$$
\text { NO. I 479, VOL. 57] }
$$

A proposal is made by the Local Lectures Syndicate for the granting of a diploma in Arts to University Extension students who have passed through a prescribed course of study and examinations.

DR. GotTlieb, assistant professor of pharmacology in the University of Heidelberg, has been provisionally appointed successor to the late Prof. Dr. W. von Schroeder.

Mr. A. E. BRISCOE has been appointed Principal of the new technical institute in course of erection at Stratford. Mr. Briscoe is at present head of the Physics and Electrical Department of the Battersea Polytechnic.

REFERRING to the London University Commission Bill, I898, which was introduced into the House of Lords by the Lord President of the Council on February 2I, and read a first time, the British Medical Journal points out that it differs from the Bill of 1897 in the omission of the names of the Commissioners. From the schedule appended to the Bill it appears that the constitution of the Senate is modified by giving to the Council of the City and Guilds of London Institute nne member, and by reducing the number of Crown nominees from five to four. The number of members of the Senate is thus retained at the same figure, fifty-five, or with the Chancellor, fifty-six. In the paragraph dealing with Faculties, the sub-section recognising examiners appointed by the University as members of the Faculties has been omitted. The instructions to the Commissioners as to examinations are practically the same, and the Senate will be required to hold separate examinations for internal and external students unless it otherwise determine, " either generally by regulation, or as to a particular subject by order." But there is this rather important addition, that the Senate will be required to communicate any such regulation to Convocation. Part II. of the Schedule is now headed, "Matters for which provision must be made." These include the adequate protection of all classes of students whether external or internal, collegiate or non-collegiate, the recognition of teachers of the University, and the regulations for the admission of internal students. The sub-clause dealing with this last point has been modified, and as it nows reads persons to be recognised as internal students will be "students who have matriculated at the University, and are pursuing a course of study approved by the University under one or more of the recognised teachers of the University."

THE official report of the Proceedings of the recent annual general meeting of the Association of Technical Institutions, containing the address delivered by the President, the Right Hon. Sir Bernhard Samuelson, Bart., F.R.S., has been issued. In the course of his remarks the President pointed out that much good will arise from the concordance between the various educational agencies which has been arrived at in ten or twelve county boroughs, one of the most conspicuous examples of which is Manchester, where the School Board, the City authorities with their splendid technical schools, and the Owens College of the Victoria University are all acting in harmony, and constructing the ladder so much talked of, but still so rarely provided, on which a child can by intelligence and perseverance mount from the humblest to the highest intellectual position. As to the expenditure of the funds available for technical in. struction. Sir Bernhard Samuelson presented the following ques. tions to his audience :- Have we fully considered the relative value of the various degrees of technical education; would it have been better for the nation if the $800,000 l$. per annum of Customs and Excise Fund had been in the main devoted to the higher rather than to the primary and secondary grades of technical education? Would not the lower grades even have been better served if we had in the first instance made a determined effort to extend and improve general elementary and secondary education? Many educationists would answer these questions in the affirmative.

\section{SOCIETIES AND ACADEMIES. LONDON.}

Royal Society, February 3.- "Researches in Vortex Motion. Part III. On Spiral or Gyrostatic Vortex Aggre. gates." By W. M. Hicks, F.R.S.

The chief part of the paper refers to a kind of gyrostatic aggregate. The investigation has brought to light an entirely new system of spiral vortices. 
The general conditions for the existence of such systems are determined, and are worked out in more detail for a particular case of spherical aggregate. It is found that the motion in meridian planes is determined from a certain function $\psi$ in the usual manner. The velocity along a parallel of latitude is given by $v=f(\psi) / \rho$ where $\rho$ is the distance of the point from the straight or polar axis. The function $\psi$ satisfies an equation of the form (when expressed in polar coordinates)

$$
\frac{d^{2} \psi}{d r^{2}}+\frac{1}{r^{2}} \frac{d^{2} \psi}{d \theta^{2}}-\frac{\cot \theta}{r^{2}} \frac{d \psi}{d \theta}=\rho^{2} F-f \frac{d f}{d \psi}
$$

where $\mathrm{F}$ and $f$ are both functions of $\psi$. The case $\mathrm{F}$ uniform, and $f \propto \psi$ is treated more fully. If $f=\lambda \psi / a$ where $a$ is the radius of the aggregate,

$$
\psi=A\left\{J_{2}\left(\frac{\lambda r}{a}\right)-\frac{r^{2}}{a^{2}} \mathrm{~J}(\lambda)\right\} \sin ^{2} \theta
$$

The most striking and remarkable fact brought out is that as $\lambda$ increases we get a periodic system of families of aggregates. The members of each family differ from one another in the number of layers and equatorial axes they possess. According to the number of independent axes they are called singlets, doublets, triplets, dic., in contradistinction to more or less fortuitous or arbitrary compounds of the former which are considered later and called monads, dyads, triads, \&c. Of these families two are investigated more in detail than the others, both because they are specially interesting in their properties and because they serve as limiting cases between the different series. In one family (the $\lambda_{2}$ family) all the members remain at rest in the surrounding fluid. In the other (the $\lambda_{T}$ family) a distinguishing feature, common to all the members, is that the stream lines and the vortex lines are coincident.

The parameter $\lambda$ gives the total angular pitch of the stream lines on the outer current sheet. The first aggregates-with $\lambda<57637$ (the first $\lambda_{2}$ value)-behave abnormally. Beyond these we get successive series, in one set of which the velocity of translation is in the same direction as the polar motion of the central nucleus, in the alternate set the velocity is opposite, and the aggregate regredes in the fluid as compared with its central aggregate.

At the end of the paper a theory of compound aggregates is developed. It is not worked out in detail in the present communication; but the conditions are determined for dyad com. pounds, whilst a similar theory holds for triad and higher ones. Each element of a poly-ad may consist of singlets, doublets, \&c. The equations of condition allow three quantities arbitrary -as for instance ratio of volumes, ratio of primary cyclic constants, and ratio of secondary cyclic constants.

At the end of the abstract, illustrations of the relations of the theory to the vortex cell theory of the ether, and to the periodic law of the chemical elements are touched upon.

February 10.--" The Development and Morphology of the Vascular System in Mammals. The Posterior End of the Aorta and the Iliac Arteries." By Alfred H. Young, M.B., F.R.C.S., and Arthur Robinson, M.D.

Though numerous observations have been made on the development of the systemic aorta and on the aortic arches, including their modifications and transformations at the head end of the embryo, but little attention has hitherto been given to the development and modifications of the primitive vessels and the aortic arches at the caudal end.

The view that the primitive aortæ are prolonged backwards from the dorsal region into the tail, and that, fusing there, they form a caudal aorta-the middle sacral artery-seems to be generally accepted by embryologists. The iliac arteries are accordingly regarded as segmental vessels.

Observations on the development of the posterior end of the aorta and its terminal branches in mammals point, however, to very different conclusions.

The primitive aortæ are not directly continued into the middle sacral artery, but into primary caudal arches, one on each side, the ventral continuations of which either fuse together to form a common vitello-allantoic stem, as in rodents, or they remain separate and form the ventral parts of the allantoic arteries, as in carnivores, ruminants and man.

The niddle parts of the primary caudal arches disappear and are replaced by "secondary" caudal arches which lie to the outer sides of the Wolffian ducts. In rodents and man the secondary arches are transformed into the common and internal iliac arteries and the dorsal parts of the hypogastric arteries, whilst in carnivores they are probably transformed into the posterior part of the adult aorta and into the internal iliacs and dorsal parts of the hypogastric arteries.

The vessels, which are to be looked upon as the posterior continuations of the primitive aorta in the adult in man, rodents, \&c., are the common iliac, internal iliac, and hypogastric arteries, and in carnivores, \&c., the internal iliac and hypogastric arteries.

The common and internal iliac arteries are not segmental vessels, their branches may be.

The middle sacral artery is a secondary branch, probably representing fused segmental vessels.

The permanent adult aorta, in so far as it is formed by the primitive dorsal aortæ, ends posteriorly either at the bifurcation into the two common iliac arteries or at a point corresponding to this bifurcation, when by more extensive fusion involving the dorsal parts of the secondary arches there are no common iliacs, and the external and internal iliac arteries appear to arise directly and separately from the aorte. In each case the continuity of the primitive aorta is interrupted; the primary caudal arches are replaced by secondary caudal arches, after which the continuations of the aorta are represented by the vessels into which the secondary caudal arches are ultimately transformed.

These conclusions are further supported by more extended observations on the anatomy of the posterior end of the aorta, and its terminal branches in mammals, and on the abnormalities they present in man.

- Further Observations upon the Comparative Chemistry of the Suprarenal Capsules, with Remarks upon the Non-existence of Suprarenal Medulla in Teleostean Fishes." By 13. Moore, M.A., and Swale Vincent, M.P.

In a previous communication these authors have shown that the paired segmental suprarenals of Elasmobranchs contain a chromogen giving the same reactions as that of the medullary portion of the suprarenal capsule of higher vertebrates, while the inter-renal body in the same order of fishes contains no such chromogen.

Now the suprarenal bodies of Teleosts do not contain the physiologically active principle which is characteristic of suprarenal medulla, and the natural conclusion would seem to be that the representative of the medulla is absent. But further evidence is desirable.

A decoction from the suprarenal bodies of Gadus morrhua and Anguilla anguilla was carefully tested for the chromogen, with entirely negative results. The lymphoid "head-kidney" was also tested, as well as other portions of the kidney, but no trace of the chromogen was found.

From these observations, combined with those previously made, the authors are forced to the conclusion that the medullary portion of the sutrarenal capsules is non-existent in Teleostean fishes.

"The Effects of Extirpation of the Suprarenal Bodies of the Eel (Anguilla anguilla)." By Swale Vincent, M B.

Teleostean fishes, having only suprarenal cortex, seemed to offer an admirable opportunity of testing how far these " cortical glands" were essential to the life of the animal. Accordingly, a series of extirpation experiments were performed upon the eèl.

In three cases in which the animals survived the operation, they appeared quite lively soon after being put back in the tank. One survived twenty-eight days, another sixty-four days, and a third was killed on the i igth day. These experiments show that an eel will survive the operation of extirpation for a very much longer time than mammals or frogs; and the difference is so striking that one must attribute it to the absence of medulla in Teleosts, and must assume that the cortical gland is not absolutely essential to the life of the animal. The longest time that a frog will survive removal of its capsules is twelve or thirteen days. Mammals usually die in a day or two.

The validity of these experiments depends upon the actual removal of all suprarenal. This was verified in two ways. (I) Previous study showed that the bodies in the eel are never more than two. (2) All three eels were dissected post-mortem, and no trace of suprarenal was found left behind.

Chemical Society, February 17.-Prof. Dewar, President, in the chair.-It was announced that the following changes in the Officers and Council were proposed by the Council. As

NO. I 479, VOL. 57] 
Vice-Presidents, Profs. Liveing and J. M. Thomson, vice Mr. L. Mond and Prof. Roberts-Austen; as Hon. Secretary, Dr. W. P. Wynne, vice Prof. J. M. Thomson; as ordinary Members of Council, Messrs. E. J. Bevan, If. J. Fenton, W. Gowland and D. Howard, vice Messrs. B. H. Brough, J. W. Rodger, T. K. Rose, and Prof. S. Young. The following papers were read:-Observations on the influence of the silent discharge of electricity on common air, by W. A. Shenstone and W. T. Evans. Air, when exposed to the action of the silent discharge, first contracts considerably and then expands to nearly its original volume; this is thus explained. Up to a certain stage in the ozonisation of atmospheric oxygen, no nitric peroxide is formed, but after this point is reached, nitric peroxide is produced, and ozone is rapidly decomposed by the silent discharge in presence of nitric peroxide, which is itself at the same time destroyed.--Some lecture ex. periments, by J. T. Cundall. The author describes lecture experiments illustrating the laws of conservation of mass and of gaseous diffusion.- Note on the preparation and properties of $o$-chlorobromobenzene, by J. J. Dobbie and F. Marsden. Orthochlorobromobenzene is a straw-coloured liquid boiling at $204^{\circ}$ under $765 \mathrm{~mm}$. pressure.-The ultra-violet absorption spectra of some closed chain carbon compounds, by W. N. I Hartley and J. J. Dobbie. The absorption of ultra-violet rays by diketohexamethylene, pyrrol, thiophene, furfurane, furfurol, pyromucic acid and furfuramide has been examined; the absorption is in some cases very intense, but no absorption bands indicating selective absorption are observed.-Note on the absorption bands in the spectrum of benzene, by W. $\mathrm{N}$. Hartley and J. J. Dobbie. - A chemical examination of the constituents of Indian and American podophyllum, by W. R. Dunstan and T. A. Henry. The constituents of Indian podophyllum (Podophyllum emodi) and of American podophyllum ( $P$. peltatum) are indentical; the chief constituent is podophyllotoxin, $\mathrm{C}_{15} \mathrm{H}_{14} \mathrm{O}_{6}$; the latter on hydration yields podophyllic acid $\mathrm{C}_{15} \mathrm{H}_{16} \mathrm{O}_{7}$, which forms a lactone, picropodophyllin, which is probably the hydroxycarboxylic acid of dimethoxymethylphenyl-hydro- $\gamma$-pyrone. An uncrystallisable resin, podophylloresin, was also isolated. - The volatile constituents of the wood of Goupia tomentosa, by W. R. Dunstan and T. A. Henry. - On oxycannabin from Indian hemp, by W. R. Dunstan and T. A. Henry, - On the condensation of formaldehyde with ethylic malonate and on cis- and trans- tetramethylenedicarboxylic acids $(\mathrm{I}: 3)$, by E. W. Haworth and W. H. perkin, jun. The condensation of formaldehyde with ethylic malonate in presence of acetic anbydride yields, in addition to ethylic propanetetracarboxylate, ethylic methylenemalonate and ethylic tetramethylenetetracarboxylate; one of the fractions on hydrolysis and elimination of carbon dioxide yieids hexahydrotrimesic acid. - Formation of ethylic dihydroxydinicotinate from ethylic cyanacetate, by S. Ruhemann and K. C. Browning.

Linnean Society, February 3.-Dr. A. Günther, F.R S. President, in the chair. - Prof. Stewart, F.R.S., exhibited (I specimens illustrative of the articulation between the upper and lower jaw of a Skate, Raia batis, Linn., upon which remarks were made by Prof. Howes and Mr. Holt ; and (2) sections of Puccinia graminis showing the form of the teleutospores and recidiospores, upon which some observations were made by Dr. D. H. Scott, F.R.S., confirmatory of the exhibitor's views. Mr. Thomas Christy exhibited a portion of an iron chain through the links of which a Virginian Creeper had grown, and had become naturally intertwined.-Mr. G. C Crick read a paper on the muscular attachment of the animal to its shell in some fossil Cephalopoda (Ammonoidea). Having first briefly noticed previous descriptions and figures of what were believed to be impressions of the muscular attachment of the Ammonoid animal to its shell, the author pointed out the form and position of the "shell-muscles" and of the "annulus" in the recent Nautilus, and indicated the form of the impression of these structures as seen upon an artificial internal cast of its bodychamber for comparison with the fossil forms, in nearly all of which any indication of the muscular attachment there may be is similarly preserved upon the internal cast of that chamber. Dr. H. Woodward, F.R.S., and Mr. B. B. Woodward offered some critical remarks.-Mr. W. C. Worsdell read a paper on the comparative anatomy of certain genera of the Cycadacere. In conclusion the author endeavoured to show that certain characters in the vegetative structure of these plants showed them to be nearly allied to, or descended from, certain fossil fern-like plants, notably the Medulloser, and these characters were : the extrafascicular zones in the stem of Cycas, which really represent the outer portion of the flattened concentric strands in the stem of the Medullosex, the inner portion of which has died out; and various concentric structures mentioned in the paper. For the type of structure prevailing in the ancestors of the Cycads would have been the concentric, whereas in their descendants it is the collateral. The significant outcome of this study is to form, in the vegetative characters of these plants, a connecting-link, over and above that already afforded by the discovery of spermatozoids in Cycas and Ginkgo, between "flowering" and "flowerless" plants. Dr. D. H. Scott, F.R.S., in criticising the paper, referred to the importance of certain facts which had been elucidated by the author and which he himself was able to confirm.

Anthropological Institute, February 22.-Mr. F. W Rudler, President, in the chair.--The Rev, H. N. Hutchinson was elected a member.-Mr. Edge Partington exhibited representations of two tattooed Maori heads, carved in Kawrie resin-_Mr. Cantrill, of the Geological Survey, exhibited a collection of objects, including a delicately-worked flint dagger or knife, obtained during his recent exploration of a cairn in Breconshire - The Rev. Archibald E. Hunt, of the London Missionary Society, read a paper on the natives of the Murray Islands in Torres Strait, with whom be had lived for three years. His studies had been directed along the lines indicated by the volume of ethnological notes and queries issued by the Anthropolngical Institute.-Prof. A. C. Haddon exhibited and explained a large series of lantern slides illustrative of the natives described by Mr. Hunt.

\section{CAMBRIDGE.}

Philosophical Society, February 7.-Mr. F. Darwin, President, in the chair.-Some zoological results of an expedition to Melanesia during the years 1894-97 (illustrated with photographic slides), by Dr. A. Willey, the Balfour Student. The paper deait chiefly with observations relating to Nautilus, Ctenoplana, Heteroplana, Amphioxus, Balanoglossus and Peripatus. An account was given of the habits, distribution, and oviposition of Nautilus. The function of the tentacular appendages of Nautilus, the ciliation of the osphradia or branchial sense-organs and of the accessory olfactory (pre-ocular and postocular) tentacles, and the distribution of the pallial, siphuncular, and genital arteries were described. In the metameric system of Nautilus, where there are indications of two segments, at least $t$ welve paired structures are repeated. The sheathed tentacular appendages of Nautilus and the arms of Dibranchiata are probably to be regarded as pedal in nature and origin, not only on account of their function, innervation and development (Dibranchiata), but also from a general consideration of the phenomena of cephalisation. The "cephalopodium" of Nautilus and the Dibranchiata was contrasted with the cephalothorax of Arthropods. Ctenoplana is probably to be estimated as a morphological type hardly second in importance to such forms as Amphioxus, Balanoglossus, Peripatus, \&c. It presents a transition from biradial to bilateral symmetry. Its pinnate tentacles, like those of the Ctenophora, lie in what corresponds to the sagittal plane of the bilaterally symmetrical Plathelminthes, and are therefore not homologous with the sensory nuchal tentacles of Polyclades as was suggested by Lang. The latter structures are represented in Clenoplana by the aboral ciliated sensory tentacles which are paired about the axis along which the pinnate tentacles lie; and in the Ctenophora by the arcuate sensory ridges and papillæ (Beroidæ) known as the polar plates, which are similarly placed with regard to the aboral sense-organ. Heteroplana was described as an anomalous Plathelminth in which the structures of the left side of the body are aborted. This condition appears to be normal for the animal, and not a phase in regeneration. Amphioxus was referred to in connection with the discovery of the West Indian subgenus Asymmetron Andrews in New Guinea waters, and also at Lifu (Loyalty Islands). The author's view that Ptychodera was a relatively primitive type of Balanoglossus was confirmed by the structure of his new genus Spengelia, which is a Glandiceps-like form possessing synapticula or cross-bars in the walls of the branchial sac, medial gonads, and vestigial roots arising from the collar nerve-cord. A new Peripatus found in New Britain was described. This form differs essentially from the groups which comprise respectively the Neotropical, Australasian and Cape species of Peripatus, and in some respects it is intermediate between the Australasian and Neotropical types. 


\section{MANCHESTER.}

Literary and Philosophical Society, February 22.Mr. J. Cosmo Melvill, President, in the chair.-The President announced that Prof. Michael Foster, F.R.S., would deliver the Wilde Lecture before the Society on March 29. - Mr. Melvill exhibited an interesting series of distortions and hyperstrophical deformities of Planorbis spirorbis, L., found by Mr. Arthur Stubbs at Black Rock, Tenby. These distortions included (I) evolute whorls, (2) various forms of carination, (3) sinistral turbinate spirals, and (4) dextral turbinate spirals. The causes for such malformations are at present practically unknown, but may be traced to the obstructions to the active but tendershelled mollusc caused by duckweed and conferva.

\section{Dublin.}

Royal Dublin Society, January I9.--The Right Rey. Monsignor Molloy in the chair.-Prof. Thomas Preston gave an account of some further observations which he had made in studying the influence of a strong magnetic field on the spectrum of a source of light placed in it. He exhibited photographs by lantern projection, which illustrated the differen types of effect, showing that doublets, quartets and sextets are produced, as well as triplets when the source of light is viewed across the lines of force. The consideration of these modifications of the normal triplet type was entered into, and it was shown how such modifications could be produced by variou forms of reversal accompanying absorption in the vapour of the spark which was the source of light. The connection of these modifications with the complexity of structure of some of the spectral lines, as observed by Michelson, was also passed in review, as well as further matters concerning the influence of the field itself on the molecules. - A paper, consisting of notes on certain Actiniaria (including Phellia Sollasi, Haddon) by Dr. Katherine Maguire, was communicated by Prof. A. C. Haddon, who also exhibited a phonograph, cinematograph, and other apparatus to be used in his projected expedition to New Guinea and Borneo.

\section{EDINBURGH.}

Mathematical Society, February II.--Mr. J. B. Clark, President, in the chair.-Mr. Duthie read a paper on a geometrical problem, by S. Guimarães.-A proposal that, in the teaching of elementary geometry, Euclid's definition of proportion be abandoned, was introduced by Prof. Gibson and Mr. W. J. Macdonald, and discussed by several of the members present.

\section{PARIS.}

Academy of Sciences, February 21.-M. Wolf in the chair. - Chemical actions exerted by the silent discharge, by $\mathrm{M}$. Berthelot. A preliminary account of the methods employed and general results obtained in the exposure of various mixtures to the action of the silent discharge. In all, more than a hundred and twenty systems were studied, the products being examined at various stages of each reaction. - Chemical actions caused by the silent discharge upon organic compounds. Gaseous systems. Hydrocarbons and nitrogen, by M. Berthelot. The action of the discharge upon the pure hydrocarbons was first studied. Marsh gas gave at first a little acetylene, which afterwards disappeared. After twenty-four hours the remaining gas was practically hydrogen, only five per cent. of the nethane being unchanged. With nitrogen, absorption takes place with the formation of basic substances. Detailed results are also given for ethane, ethylene, acetylene, prophylene, trimethylene, and allylene, both alone and mixed with nitrogen.On derivatives of cinchonine, by M. E. Grimaux. Several derivatives are described of the brominated substance obtained by adding bromine to the crude oxidation product of cinchonine according to the method of Konigs and Comstock.-On the place of the sponges in classification, and on the signification attributed to the embryonic leaflets, by M. Edmond Perrier. A criticism of a note on the same subject by M. Delage.-On iteration, by M. C. Bourlet.-Remarks on a note by M. Moreau on cycles of magnetic torsion and the residual torsion of soft iron, by M. H. Bouasse. The two laws announced by M. Moreau on residual torsion can be easily deduced from known facts. - On an analogy between the action of luminous rays and of lines of magnetic force, by M. Birkeland. A Crookes' tube is placed above an electromagnet, and is so arranged that the distance of the kathode from the magnet can be exactly regulated. Beyond a certain distance, the discharge in the tube is uninfluenced by the magnet, but as the tube gradually ap- proaches there is a certain critical position at which all the properties of the discharge are suddenly changed, the difference of potential between the kathode and anode being reduced to a tenth of the original value, and the kathode rays are replaced by others which produce no phosphorescence in the tube. The critical distance increases with the strength of the magnetising current. - On the preponderance of the mechanical action of convection currents in the production of effluvia figures upon fogged plates submitted to the action of thermic poles in developing baths, by M. A. Guébhard.-On a combination of phosphoric anhy. dride with benzene, by, M. H. Giran. The compound described is obtained by heating the two substances in a sealed tube at $120^{\circ}$. It is decomposed by water, and appears to be $\mathrm{C}_{6} \mathrm{H}_{6}+$ ${ }_{4} \mathrm{P}_{2} \mathrm{O}_{5}$. - Influence of the X-rays upon the phenomenon of osmosis, by M. H. Bordier. The experiments show that in spite of the interposition of an aluminium plate in communication with the ground, osmosis is much slower when the apparatus is exposed to the X-rays. - Production of a mucinoid substance by bacteria, by MM. A. Charrin and A. Desgrez. A substance of an albuminoid nature is produced by the growth of the pyocyanic bacillus in beef broth. This possesses poisonous properties, a dose 0.15 grams per kilogram proving rapidly fatal to a rabbit. Other bacilli behave similarly.-On bitterness in wines, by MM. J. Bordas, Joulin, and Rackowski. A ferment has been isolated, to which the production of the bitterness in wine appears to be due.-On the aptitude of the spores of the truffle to germinate, and on the function of the aroma, by M. A. de Gramont de Lesparre. The aroma assists in the preservation of the species by its antiseptic action upon the spores.-On ktypeite, a new form of calcium carbonate, differing from both calcite and arragonite, by M. A. Lacroix.The new form is found in the crystalline deposits of the thermal springs of Carlsbad and Hammam-Meskoutine. Heat transforms the mineral into calcite, with detonation.- Semolina and foods resembling vermicelli or macaroni, by M. Ballard. Analyses of semolina and macaroni from various sources. The quality appears to be in proportion to the amount of nitrogenous material.

\section{New South Wales.}

Royal Society, December I, 1897.-The President, Henry Deane, in the chair. - On the steady flow of water in uniform pipes and channels, by G. H. Knibbs. The paper dealt generally with the nature of the two régimes under which flow takes place, and of the instability of the rectilinear flow in pipes. A general formula was proposed, to express the mean velocity of a flow of water in a circular pipe under either régime, at any temperature, and with any radius, "slope," or material of pipe.-Experimental investigation of the flow of water in uniform channels, by S. H. Barraclough and T. P. Strickland. The main object of this investigation was to fill in an hiatus in the existing series of experimental results, by determining the effect of change of slope upon the velocity of flow, when the slope is varied over a wide range.-Current Papers, No. 3 , by H. C. Russell, C.M.G., F.R.S. This paper will be printed in vol. xxxii. of the Society's Proceedings for I898. - Notes on Myrticolorin, by Henry G. Smith. In the abstract of proceedings for August 4, a paper by Mr. Smith is noticed wherein is announced a new dye-stuff obtained from the leaves of the "Red Stringy Bark," Eucalyptus macrorhyncha. This material, which in some respects is allied to aromadendrin, was stated to belong to the quercetin group of natural dyes. It was named by the author Myrticolorin, as it was supposed to be the only true dye substance obtained from the Myrtacex. This note amplifies previous statements by recording the results arrived at since the announcement above referred to. Myrticolorin is a glucoside of quercetin, and it breaks up on boiling with dilute sulphuric acid into quercetin and a sugar. $-\mathrm{A}$ second supplement to a Census of the Fauna of the Older Tertiary of Australia, by Prof. Ralph Tate, with an appendix on Corals, by John Dennant. Prof. Tate begins his paper by giving references to the principal contributions to Australian Tertiary Palæontology which have appeared since the publication of his first supplement in the Journal of this Society for 1888 . He notes a number of genera hitherto unrecorded as being represented in Australia. In the Polyzoa, a synopsis is given of McGillivray's work, this author being almost entirely responsible for the very large additions to the genera and species of our Eocene fauna. Mr. Dennant's appendix is prefaced by a brief résumé of recent work on Australian Tertiary Corals. He then proceeds to record two hitherto unrecorded genera for the Australian Tertiary Corals. 


\section{Göttingen.}

Royal Society of Sciences - - The Nachrichten (mathematico-physical section), part 3 (I897), contains the following scientific papers communicated to the Society :-

May 29.-E. Wiechert: The distribution of matter in the interior of the globe.

Octnber 30,-W. Wirtinger: Green's function for a region bounded by non-intersecting spherical continuta of $n$ dimensions. $\mathrm{K}$. Hensel : Determination of the discriminants of an algebraical corpus. K. Hensel : The fundamental equation and the nonessential discriminant-divisors of an algebraical corpus.

November I3.--W. Voigt: Further contributions to the kinetic theory of the process of evaporation.

November 27.-A. Hurwitz: The coefficients of development of the lemniscate-functions. G. Landsberg: On modular systems of the second grade and rings of numbers. $O$. Wallach : Researches from the Göttingen University Chemical Laboratory - (I) Cisisomerism and transisomerism in the menthol series; (2) ketones $\left(\mathrm{C}_{10} \mathrm{H}_{16} \mathrm{O}\right)$ from terpinene-nitrite; (3) reduc tion-products of carvone and eucarvone ; (4) a new isomeric camphor from pinene; $(5)$ on pulegenic acid; $(6)$ new compounds from methylhexanone; (7) on fenchone-derivatives.

The official section, part 2 (1897), gives the text of an anniversary address by Dr. F. Merkel, on " the forces which mould the forms of animal bodies," and a report on a journey through Colombia and Venezuela by Prof. O. Bürger.

\section{DIARY OF SOCIETIES.}

THURSDAY, MARCH 3 .

Roval Societr, at 4.30 . - The Relationship of Variations of the Ground Water Level to th- Incidence of Malarial Fevers in Chotta Nagpur. Bengal: Dr L.. Rogers.--On the Depletion of the Endosperm of Hordew vulgare during Germination: H. T. Brown, F.R.S., and F. Escombe.-On Apogamy and the Development of Sporangia upon
Fern Prothalli : W. H. Lang and G. A. Clark-Experimental Of, Fern Prothalli : W. H. Lang and G. A. Clark-Experimental Of, Organs of Muscles: Dr. F. E. Batten.

Roval. Institurion, at 3.-Recent Researches in Magnetism and Diamagnetism: Prof. J. A. Fleming, F R.S.

Linnean Sucieir at 8.- On the Sense Organs of the Lateral Line in certain Fishes: F. J. Cole -On the Occurrence of Carex helvolx in Britain : G C. Druce.--On Arctic Spiders from Franz Josef J and : Rev O. Pickard-Cambidge.

Chemical Societr, at 8. Note on the Preparation of Dry Hydrogen Cyanide and Carbun Monoxide: John Wade and Iawrence C. Ponting.-Production of some Nitro- and Anido-Oxylutidines: Dr. J. N. Colle, F.R S., a.d T. Tickle--Production of some Nitro- an Interaction of Magnesium and Solution of Copper Sulphate : Dr. E. Divers, F.R.S.

$$
\text { FRIDAY, MARCH } 4 \text {. }
$$

Royal Institution, at 9.-Some Recent Results of Physico. Chemical Inquiry: Prof. T. E. ? horpe, F.R.S.

$$
\text { И() } \cup \cap A Y, \text { MaRCH }
$$

Socierv of 1 is, at 8.- The Principles of Design in Form: Hugh Stannus.

IMPERIAL INSTITUTE, at 8.30. - The Mineral and other Resouries of Newfoundland: J 11 Collins.

VICTIRIA INSTITUTE, at 4.30 -The Design of the Human Foot: Gerald Smith.

$$
\text { TUESUA', MarCH } 8 .
$$

Rovai, Instirumilin, at 3.-The Simplest Living Things: Prof. E. Ray

Laikester, F.R.S
Society $\because F$ AR's, at 8. - The Making of a Stained Glass Window : Lewis Foreman Day.

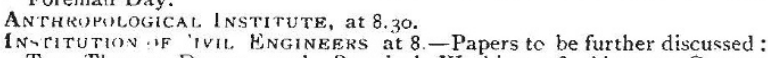
The Theory Deign, and Practical Working of Alternate-Current M tors: Llewelyn B Atkinson.-Dublin Electric Tramway: H F. Parshall.-Paper ro be read with a view to Discussion : Calcium Carbide and Acetylene : Henry Fowler.

R yat A J Ficuliural Sociery. - Floral and Botanical Demonstration KuY iL PHirinik+PHIl FoCIFIV, at 8. - The Passage of a few of the Salts used in Photography through Gelatine Septa: A. Haddon.

RuY +2 VICToria HALL, at 8.30.-A Work of Faraday: Prof. Reinold.

$$
\text { (WF' } \backslash \text { ES" } A Y \text {. MARCH } 9
$$

SOCIE 'Y OF ARTS, ar 8.-Linde's Method of producing Extreme Cold and Liquefying Air: Prof. J. Ewing, F.R.S.

Geological Societr, at $8-\mathrm{N}$, te on Llipperton Atoll : Rear-Admiral Sir W.J Wharton, K.C. B, F.R.S. - I Phosphatised Trachyte from Clipper-
W. The W. J Wharton, K.C.B , F.R.S. - I Phosphatised Trachyte from Clipper-
$t$ in At.ll : f f. H. Teall, F.R.S. - The Pliocene Deposits of the Eist of tin At.ll : J f. H. Teall, F. R. S. The Pliocene Deposits of the East of
Engl ind. Part I. The Lenham Beds and the Coralline Crag: F. W.
Harmer.

R Y YAL SUCIETY, at $4 \cdot 30$.

$$
\text { THURSIAY, MARCH to. }
$$

ivil. IN $>$ TITUTION, at 3.-Recent Researches on Magnetism and Diainasnetism : Prof, J A. Fleming, F.R.S.

Sociciv of ARTs (Indian Section), at 4.30.-India and Sir Henry Maine Charles Lewis Tupper, C.S.I.

M I r B MATtCaL Societr, at 8. - The Geodesic Geometry of Surfaces in
non- Huclidean Space: A. N. Whitehead.-The Transformation of Linear Partial Differential Operators by Extended Linear Continuous Groups :

$$
\text { No } 1479 \text {, VoL. } 57]
$$

Pr ,f. Elli ott, F.R.S.--Stereographic Illustrations of Catenaries: Prof, Greenhill, F.R S., and T. I. Dewar.

institution of EI.ECTRICAL ENGINeERs, at 8.-On the Manufacture of Iamps and other Apparatus for 200 volt Circuits: G. Binswanger. Byng.

FRIDA', MARCH IT.

Royal Institution, at 9.-Marked Unexplored: W. F. Lurd.

Roval Astronomical Society, at 8.

Institution of Civil Engineers, at 8.-The Drainage of Cottage Property: H. C. Adains.

Malacological Societr, at 8 .

\section{BOOKS, PAMPHLET, and SERIALS RECEIVED.}

Books.-General Report on Public Instruction in the North-West Pro vinces and Oudh, 1896-97 (Allahabad).-Who's Who, 1898 (Black).-First Year of Scientific Knowledge: P. Bert, revised edition (Relfe). - Th Wealth and Progress of New South Wäles, r895-96: T. A. Coghlan, Vol. 2 (Sydney, Gullick). -Das Weltgebäude : Dr. M. W. Meyer (Leipzig, Bibliographisches Institut).-Universal Electrical Directory, 1898 (Ala baster).-The Miner's Arithmetic and Mensuration: H. Davies (Chapman). A Sketch of the Natural History (Vertebrates) of the British Islands : F G. Aflalo (Blackwood).-Semitic Influence in Hellenic Mythology: R Brown, jun. (Williams).-A Description of Minerals of Commercial Value D. M. Barringer (Chapman). - Report on the Economic Resources of the West Indies: Dr. D. Morris (Eyre). - The Electrician Electrical Trades Directory and Handbook for 1898 (Electriciast Office).-Der Täglich Wärmeumsatz im Boden und Die Wärmestrahlung Zwischen Hımmel und Erde: Dr. T. Homén (Leipzig, Engelmann). - The Chemistry of the Gurden: H. H. Cousins (Macmillan)-Note-Book of Agricultural Fact and Figures f r Farmers and Farm-Students: P. McConnell, 6th edition (1.ockwood). - Notes from a Diary, $1873-1881$ : Sir M. E. Grant Duff, 2 Vols. (Murray).- Report of Observations of Injurious Insects and Commo Farm Pests : E. A. Ormerod, 21st Report (Simpkin).-Grundzüge der Geographisch-Morphologischen Methode der Pflanzensystematik: Dr. R. v. Wettstein (Jena, Fischer). - The Naturalist's Directory, 1898 (Gill)

Pamphlet.-La Teoria dei Raggi Roentgen : Prof. Filippo Re (Palermo, Reber)). SERIALs,-American Naturalist, January (Boston, Ginn).--Himmel und
Erde, February (Berlin, Paetel).-Bulletin of the American Mathematical Erde, February (Berlin, Paetel). - Bulletin of the Americian Mathematical
Society. February (New York, Macmillan). - Natural History Transac. Society. February (New York, Macmillan), - Natural History Transac-
tions of Northumberland, Durham, and Newcastle-on-Tyne, Vol. xiii. tions of Nurthumberland, Durham, and Newcastle-on-Tyne, Vol. xui.
Part. 2 (Williams). - Longman's Magazine, March (Longmans).-Good Part 2 (Williams).-Longman's Magazine, March (Longmans),-Good
Words, March (Islbister).-Sunday Magazine, March (Isbister).-HumanjWords, March (Islister). - Sunday Magazine, March (Isbister). - Humanitarian, March (Hutchinson).-Chambers's Journal, March (Chambers).-
Botanische Jahrbücher, Vierundzwanzigster Band, iv. Heft (Leipzig). Botanische Jahrbücher, Vierundzwanzigster Band, iv. Heft (Leipzig).
- Natural Science, March (Dent).-Contemporary Review, March (Isbister) - Century Magazine, March (Macmillan).

\section{CONTENTS.}

PAGE

Archimedes. By R. E. B. . . . . . . 409

A New Text-Book of Experimental Physiology : 410 Our Book Shelf:

"L. Riitimeyer"

Rigollot: "Recherches expérimentales sur quelques

Actinomètres Electro-chimiques"
"Neudrucke von Schriften und Karten über Meteorologie und Erdmagnetismus" . . . . . . . . 412

\section{Letters to the Editor:-}

Does a Phosphorescent South American Liana exist ? - Prof. Italo Giglioli

Insusceptibility of Insects to Poisons, $-\dot{M}$ iss $\dot{H}$. $\mathbf{B}$. Potter

The Mandrake-Kumagusu Minakata

Antarctic Research. (With Chart.) By Dr. Hugh Robert Mill

Ernst Christian Julius Schering. By W. H. and G. Chisholm Young . . . . . . . . . . . . 416

\section{otes}

Our Astronomical Column :-

Eclipse Negatives . . . . . . . . . . . . . . $4 \mathrm{I} 9$

Cinematograph in Astronomy . . . . . . . . 419

A Probable New Star . . . . . . . . . . . . . . 4I9

Electrolytic Reflectors . * * * 419

Scientific Advantages of an Antarctic Expedition. Addresses by Dr. John Murray, F.R.S., the Duke of Argyll, Sir Joseph Hooker, G.C.S.I., F.R.S., Dr. Nansen, Prof. Dr. Neumayer, Sir Clements Markham, K.C.B., F.R.S., Dr. Alex. ander Buchan, Sir Archibald Geikie, F.R.S., Dr. P. L. Sclater, F.R.S., and Prof. D'Arcy Thompson the Absorption of Light by Fluorescing Bodies. (With Diagram.)

The Structure of Crystals

University and Educational Intelligence . . . . . 428

Societies and Academies . . . . . . . . . . . . 428

Diary of Societies . . . . . . . . . 432

Books, Pamphlet, and Serials Received: . . 432 